UDC 336.73

DOI: https://doi.org/10.32782/2413-9971/2020-29-10

Esh Svitlana
Senior Lecturer at the Department of Finance,
National University of Food Technologies

Hnatenko Olena

Ph.D. at the Department of Finance, National University of Food Technologies

EII C. M. старший викладач кафедри фінансів Національного університету харчових технологій

Гнатенко О. А.

кандидат економічних наук, доиент кафедри фінансів

Національного університету харчових технологій

\title{
THEORETICAL AND PRACTICAL ASPECTS \\ OF THE ACTIVITIES OF NON-BANKING FINANCIAL INSTITUTIONS AND THEIR ROLE IN THE DEVELOPMENT OF THE MODERN FINANCIAL SERVICES MARKET IN UKRAINE
}

Summary. The article proposes a scientific approach to determining the place and role of non-banking financial institutions in the development of the financial services market. Non-banking financial institutions are considered as the main intermediaries of the financial market, the activities of which are aimed at creating special insurance and protection systems against financial risks, increasing the return on credit capital, and reducing costs associated with the creation of new financial products for market entities. The authors analyze the activities of specialized financial intermediaries who are engaged in the market with one type of activity: insurance companies, credit unions, private pension funds and pawnshops, which are the most common institutions in the domestic financial services market. The article analyzes the quantitative and qualitative indicators that determine the role of financial intermediaries in the financial services market of Ukraine. The problems that impede the development of non-banking financial institutions are highlighted and ways to solve them are proposed.

Key words: Financial services market, non-banking financial institutions, insurance companies, non-state pension funds, credit unions, pawnshops.

Introduction and problem definition. The main intermediaries in the financial market and its segments are banking and non-banking financial institutions (NBFIs). Banks and NBFIs operate in the same market, in the same environment, generate financial resources through the emission of financial assets, and have the shared objective of satisfying the interest of consumers' financial services. Regardless of the fact that both banking and NBFIs have a lot in common, the role of international in the financial services market belongs to banks, but under the current conditions of management, the role of NBFIs is also significantly increasing.

In the process of providing services, according to international experience, the activities of NBFIs may prove to be more effective than those of banks. For example, when providing one or two services, activities are concentrated and conditions are created to improve the quality of such services. At the present stage, when the domestic economy needs longterm and cheap capital to implement innovation processes, the role of non-banking financial institutions, accumulated financial resources of which are additional course of economic growth in the country and is significantly increasing.

It is NBFIs that play a special role in the overall development of certain economic sectors (credit, currency, fund, etc.), which during the attraction and redistribution of funds play an important socio-economic function aimed at the forming of investment and innovative model of domestic economy. Each year, the role and importance of NBFIs in the services market is growing. This is due to the growing demand for NBFIs services for banks (leasing, insurance, forfeiting, factoring, trust) with rising income levels, with the active institutional development of the non-banking sector, etc. in this regard, it is important to analyze the performance of modern non-banking financial institutions operating in the financial services market.

The analysis of the recent reaserch and publications. The theoretical and practical aspects of non-banking financial establishments in the development of the market of financial services are devoted to the work of many domestic scientists, in particular: O.M. Gladchuk [1], M.V. Gutsa, L.V. Didenko [2], I.A. Kobzar, A.L. Dorosh, M.V. Dubyny [3], O.M. Ivanytska [4], O.P. Sidelnyk [5[, E. Polishchuk [6] and others. Among foreign scientists it is necessary to notice F.A. Mishkina, R.O. Kurbanbekova, M.G., Nazarova [6], who research NBFIs at the market of their countries, analyze their activities and determine their role in economic development.

The purpose of the article is to research and substantiate the activity of NBFIs in the domestic market of financial services, to determine their role in the development of the country's economy, to highlight the main problems of their functioning and to find out the directions for their solutions.

Research results. The traders and money lenders began to provide the first services, which are specific for NBFIs, in the Middle Ages. The first NBFIs, as a separate elements of the credit system, began to form in the XIX century. In the matter of services, the first NBFIs (factoring, leasing, forteiting, depository) began to develop together with the financial market in the $20^{\text {th }}$ centry. Banking institutions focused on traditional services that were in high demand by the popula- 
tion: cash and settlement services, deposit and credit operations, funds transfer, guarantees,etc. accordingly, various NBFIs began to fill the segment of risk services in the market. Nowadays, a wide range of services provided by NBFIs is a sign of development of the financial and economic system of the state.

NBFIs, as were noted by all researches [1-6], are highly specialized financial intermediaries, main functions of which are to provide insurance protection of the population and economic entities (insurance companies), granting small loans (investment companies), repayment of receivables (factoring companies), diversification of investing areas by business entities (trust, securities traders, asset management companies) and others that banks perform and not profitable. One NBFI may provide services related to diferent market segments at the same time. For example, non-state pension funds accumulate national currency in the money market and invest it mainly in shares of private companies in the international and domestic stock markets. Credit unions provide the development of the deposit and credit segements of the financial market, which, ultimately, contributes to the development of the economy of the country through the capital flow from one industry to another.

Currently, there are diferent types of NBFIs in the domestic financial services market. The perfect qualification was given by Ye. Polishchuk [6], who divided and researched NBFIs according to different characteristics. To determine the role of NBFIs in the development of modern domestic financial service market, according to the authors, the activities of NBFIs is analysed into three types:

1) group of NBFIs operating on the basis of concluded contracts: insurance companies, non-state pension funds, leasing and factoring companies, pawnshops, depository institutions;

2) deposits of NBFIs: credit unions, building socienties;

3 ) investment and financial NBFIs: financial companies, investment funds, credit companies.

According to the information of National Commission for Regulation of Financial Services Markets given in Table 1, the analysis of NBFIs number is operated in the financial services market at the end of the quarter of the relevant year.

According to the State Register of Financial Institutions (Table 1), at the end of the 3rd quarter of the relevant year, there were 2014 financial institutions in Ukraine, total assets of which amounted to 187.3 billion UAH at the same date. This is almost nine times smaller than in banks, but at the same time there is increase in assets in the non-banking sector by $9 \%$, while in the banking sector, the comparable data is less than $2 \%$ [8].
During 3 years, the total number of NBFIs decreased by 101 institutions. Only financial companies (factoring, leasing, investment) the number of which increased by 131, show a positive growth trend. Among financial companies, the largest number (589 units) at the end of 2018 provided services to factoring institutions, which during the 2018 concluded 29024 units of contracts worth 48105 million UAH [7]. The largest decrease was observed among credit unions: 104 of which were closed. There is also a decrease in pawnshops,where 97 units of them were closed during the period of 3 years.

This reduction, according to the authors, is associated with the preparation and adoption of the law, which is called the "Split Law". The law, approved by the deputies and signed by the President, is the result of the joint work of financial sector regualrtors and international experts and provides the following changes [8]:

- liquidation of the National Commission for Regulation of Financial Services Markets (National Commission). Within the framework of the law, by 30 June 2020 the National Bank of Ukraine will be in charge of regulating the market, but from June 1, 2020 this function will be performed by the National Bank of Ukraine;

- regulation of insurance, leasing, financial companies, credit unions, pawnshops and credit bureaurs will be transferred to the National Bank of Ukraine;

- the National Securities and Stock Market Commission will be empowered to regulate and oversee the non-state pension system, as well as the functioning of financial and credit mechanisms and property management in the construction of housing and real estate operations.

It is envisaged that the Split Law will enable [8]:

- to provide balances and systematic approach towards the effective development of the non-banking financial sector;

- to move from a sectoral model of financial services market regulation to more efficient integrated model;

- to create preconditions for the complex development of the function of regulation of market behaviour of business entities;

- to protect the rights of consumers in the financial market.

Important segment of domestic financial services market is the insurance market, which takes the second place in terms of capitalization among other NBFIs. Insurance companies in the financial services market act, on the other hand, as financial institutions that raise and distribute cash for income, and on the other hand, as organisations that redistribute and hedge the financial risks of other market entities.

The number of insurance companies in the market has been showing the downward trend for a long time. Compared to the same period of 2017, their number decreased by 7 insurance companies (Table 1). The main indicators of the insurance market dynamics are presented in Table 2.

Table 1

Ananlysis of number of NBFIs and their assets (at the end of the $3^{\text {rd }}$ quarter of recent year)

\begin{tabular}{|l|c|c|c|c|c|c|c|c|}
\hline \multirow{2}{*}{ Name of NBFIs } & \multirow{2}{*}{$\mathbf{2 0 1 6}$} & \multirow{2}{*}{$\mathbf{2 0 1 7}$} & \multirow{2}{*}{$\mathbf{2 0 1 8}$} & \multirow{2}{*}{$\mathbf{2 0 1 8 / 2 0 1 6}$} & \multicolumn{4}{c|}{ Assets, million UAH } \\
\cline { 6 - 10 } & & & & $\mathbf{2 0 1 6}$ & $\mathbf{2 0 1 7}$ & $\mathbf{2 0 1 8}$ & $\mathbf{2 0 1 8} / \mathbf{2 0 1 6 ,} \%$ \\
\hline Financial companies & 809 & 818 & 940 & 131 & 107.7 & 121.0 & 118.7 & 10.3 \\
\hline Insurance companies, as well: & 310 & 294 & 281 & -29 & 55.4 & 56.8 & 59.5 & 1.3 \\
\hline - non-life & 271 & 261 & 251 & -20 & 44.7 & 45.7 & 47.7 & 1.07 \\
\hline- life & 39 & 33 & 30 & -9 & 10.7 & 11.2 & 11.8 & 1.09 \\
\hline Loans associations & 462 & 378 & 358 & -104 & 2.2 & 2.2 & 2.4 & 1.07 \\
\hline Non-govermental pension funds, & 86 & 86 & 84 & -2 & 2,1 & 2,3 & 2,7 & 1,28 \\
as well managers of NPF & 22 & 22 & 22 & - & - & - & - & - \\
\hline Pawnshops & 456 & 415 & 359 & -97 & 3.2 & 3.5 & 4.0 & 1.25 \\
\hline Incorporated enterprises & 2 & 2 & 2 & - & - & - & - & - \\
\hline Sum total of national registry & 2125 & 1993 & 2024 & -101 & 170.6 & 185.8 & 187.3 & 1.09 \\
\hline
\end{tabular}

Designed by authors according to the source [7] 
Main indicators of the activities of insurance market of Ukraine

\begin{tabular}{|l|c|c|c|c|}
\hline \multicolumn{1}{|c|}{ Indicators } & 9 months 2018 & 9 months 2019 & \multicolumn{2}{c|}{ Growth rate } \\
\cline { 3 - 5 } & $\mathbf{2 0 1 9 / 2 0 1 8 , ~ a b s . ~}$ & $\mathbf{2 0 1 9 / 2 0 1 8 , ~ \% ~}$ \\
\hline $\begin{array}{l}\text { Number of insurance contracts, except compulsory } \\
\text { accident insurance contracts for transport, thousand of units }\end{array}$ & 58648.7 & 60930.4 & 2281.7 & 3.9 \\
\hline $\begin{array}{l}\text { Number of contracts for compulsory accident insurance on } \\
\text { transport, thousand of units }\end{array}$ & 94663.8 & 88658.8 & -6005 & -6.3 \\
\hline Gross insurance bonuses, million UAH & 34875.3 & 40561.9 & 5686.6 & 16.3 \\
\hline Growth insurance payments & 8754.8 & 98845.6 & 1090.8 & 12.5 \\
\hline Net insurance bonuses & 25388.5 & 30149.4 & 4760.9 & 18.8 \\
\hline Net insurance payments & 8467.0 & 9624.3 & 1157.3 & 13.7 \\
\hline Paid for reinsurance, million UAH & 11718.5 & 12930.7 & 1212.2 & 10.3 \\
\hline Insurance reserves, million UAH & 24833.2 & 29661.3 & 4828.1 & 19.4 \\
\hline Total assets of insurance companies, million UAH & 59468.2 & 66950.6 & 7482.4 & 12.6 \\
\hline Amount of paid-up share capital & 12565.8 & 11672.0 & -893.8 & -7.1 \\
\hline
\end{tabular}

Designed by authors according to the source [9]

The data from the Table 2 indicate the increase in the number of insurance contracts concluded over the last two years, which has led to the increase in economic indicators. The total assets of insurers increased by 7482.4 million UAH $(12.6 \%)$ and the amount of insurance reserves by 4828.1 million UAH (19.45) which are financial sustainability indicators and reflect the ability of the company to fulfil their obligations in the future.

Important component of the financial services market is non-state pension funds (NPFs). NPFs are specialised financial intermediaries that accumulate funds of legal enitites and individulas in trust funds on a contractual basis from which they make pension payments to citizens after reaching a certain age. The main indicators of the activity of non-state pension funds and their growth rates are summarised in Table 3.

The mechanism of operation of NPFs is as the life of insurance companies, where contributions to the fund are made systematically over a period of time, as a result, the large sums of cash are accumulate. The results of the NPF analysis (Table 3 ) show the dynamics of growth over the last 3 years of all indicators. Pension contributions from individuals increased almost twice (by $86.7 \%$ ). This increase is due to the increase in the number of NPF participants (by $2.6 \%$ over 3 years) and the increase in the number of concluded pension contracts by
6.2 thousand of units $(9.9 \%)$. Important factor for the development of NPFs is the result of investing the assets that NPF administrators mainly invested in securities. Over the past 3 years, we have seen an increase in the amount of investment income by 687.2 million UAH (63.6\%) and an increase in the return on investment of assets by 605.7 million UAH (72.6\%).

The prawnshops are the important institutional component of the financial services market. Their main advantage over banking institutions is that they do not require clients to provide income, residency, credit card information. Pawnshops remain one of the most conservative and stable financial institutions for the population, because their activities are focused on the insurance of small and short-term loans, the subject of the pledge is usually the most liquid property: gold and silverware. Thus, in the volume of financial loans granted by type of collateral, the largest share is taken by financial loans secured by precious stones and precious metals of $76 \%$, loans secured by household appliances are $23.6 \%$ [10].

On the $31^{\text {st }}$ of December, 2018, there were 359 pawnshops and 6171 separate units in the State Register of Financial Institutions.

It is planned to regulate the activity of pawnshops in a new way in Ukraine. Thus, on December 26, 2019, the bill was published, the main purpose of which was to ensure the stable

Dynamics of the main indicators of non-state pension funds' activities

Table 3

\begin{tabular}{|l|c|c|c|c|c|}
\hline \multicolumn{1}{|c|}{ Indicators } & \multirow{2}{*}{$\mathbf{2 0 1 6}$} & $\mathbf{2 0 1 7}$ & $\mathbf{2 0 1 8}$ & \multicolumn{2}{c|}{ Growth rate, \% } \\
\cline { 4 - 6 } & & & $\mathbf{2 0 1 8} / \mathbf{2 0 1 7}$ & $\mathbf{2 0 1 8} / \mathbf{2 0 1 6}$ \\
\hline Number of concluded pension contracts, thousand of units & 62.6 & 58.7 & 68.8 & 17.2 & 9.9 \\
\hline The total number of NPF participants, thousand of people & 834,0 & 840.8 & 855,3 & 1.7 & 2.6 \\
\hline Total value of NPF assents, million UAH & 2138.7 & 2465.6 & 2745.2 & 11.3 & 28.4 \\
\hline Total pension contributions, million UAH & 1895.2 & 1897.3 & 2000.5 & 5.4 & 5.6 \\
\hline as well as: & & & & & \\
\hline - from individuals; & 92.2 & 124.3 & 172.1 & 38.5 & 86.7 \\
\hline - from individual enterpreneurs; & 0.2 & 0.2 & 0.2 & 0.0 & 0.0 \\
\hline - from legal entities; & 1802.1 & 1772.3 & 1827.7 & 3.1 & 1.4 \\
\hline Pension payments, million UAH & 629.9 & 696.3 & 809.9 & 16.3 & 28.6 \\
\hline $\begin{array}{l}\text { Number of participants received/ receiving retirement } \\
\text { benefits, thousand of people }\end{array}$ & 81.3 & 78.8 & 81.3 & 3.2 & 0.0 \\
\hline The amount of investment income, million UAH & 1080.5 & 1455.5 & 1767.7 & 21.4 & 63.6 \\
\hline Profit from investment of assets of NPF, million UAH & 834.8 & 1183.9 & 1440.5 & 21.7 & 72.6 \\
\hline $\begin{array}{l}\text { Amount of expenses reimbursed from retirement assets, } \\
\text { million UAH }\end{array}$ & 245.7 & 271.5 & 327.2 & 20.5 & 33.2 \\
\hline
\end{tabular}

Designed by authors according to the source [7] 
Table 4

Analysis of indicators of pawnshops' activities (million UAH)

\begin{tabular}{|c|c|c|c|c|c|}
\hline \multirow{2}{*}{ Indicators } & \multirow{2}{*}{2016} & \multirow{2}{*}{2017} & \multirow{2}{*}{2018} & \multicolumn{2}{|c|}{ Deviation } \\
\hline & & & & 2018/2016, абс. & $2018 / 2016, \%$ \\
\hline Number of pawnshops (units) & 456 & 415 & 359 & -97 & -21.3 \\
\hline Balance sheets assets & 3317.7 & 3763.7 & 3721.3 & 403.6 & 12.2 \\
\hline Accounts receivable, including: & 2630.8 & 2857.7 & 2827.8 & 197.0 & 7.5 \\
\hline on financial loans provided & 1578.2 & 1596.0 & 1789.2 & 211.0 & 13.4 \\
\hline on accured interest on financial loans & 54.0 & 66.2 & 90.7 & 36.7 & 67.9 \\
\hline Share capital & 1250.3 & 1352,4 & 1468.8 & 218.5 & 17.5 \\
\hline Reserve capital & 48.5 & 61.6 & 77.1 & 28.6 & 58.9 \\
\hline Undivided profit & 415.3 & 504.2 & 589.5 & 174.2 & 41.9 \\
\hline Equity, total number & 1481.6 & 1648.5 & 1867.2 & 385.6 & 26.0 \\
\hline Funds raised on paid and free basis & 192.1 & 168.2 & 156.2 & -35.9 & -18.7 \\
\hline
\end{tabular}

Designed by authors according to the source [7]

development and operation of pawnshops, to create a competitive environment in the services market and ensuring the protection of the interests of consumers of such services [10]. According to the bill, pawnshop is a financial institution, the activity of which is to provide at its own risk financial loans secured by movable property for a fixed term or for interest and other activities, which are also provided.

The analysis of pawnshops in the financial services market is presented in Table 4.

The analyzed indicators of the financial status of the pawnshops over the 3 years show the balance sheet assets increase; authorized, reserve and equity; retained earnings. Equity increased by 385.6 million hryvnas $(26 \%)$, retained earnings by 174.2 million hryvnas $(41.9 \%)$, which is positive in the pawnshops' activity, but over 3 years there is a tendency to reduce the number of pawnshops by 97 units. Accordingly, this reduction has led to the decrease in borrowed funds on paid and free basis.

Let us analyze the activities of their NPFs, in particular credit unions, which are non-profit organisations, founded by individuals, trade unions and their associations with the aim to meet the needs of its members for mutual lending of financial services at the expense of pooled cash contributions.

The results of the activities of credit unions and the dynamics of their main indicators are summarised in Table 5.

The data in Table 5 indicate a decrease in the number of credit unions over 104 financial institutions (22.5\%) over 3 years, and a corresponding decrease in the number of their members in the same period is aslo reduced by 163 thousand $(25.4 \%)$. But the total assets of credit unions show a tendency to increase by 185.9 million $(9.1 \%)$, members' contributions to deposit accounts also increase by 213.9 million $(25.7 \%)$, which testifies to the possible merger of these financial institutions.

Despite the rapid development of non-banking financial institutions in the financial services market over the lst year, there are a number of problems at the present stage:

- lack of transparency in the activities of the NPFs. Nowadays, the level of disclosure of information by NPFs to consumers and regulators does not allow to make the right decisions regarding the use of financial services and the effective supervision of non-banking financial institutions;

- low level of sustainability and competitiveness of the NPFs in the current market for services, which is associated with a low level of capitalization and is a serious obstacle to provide the economy with long-term financial resources;

- lack of information on the financial services provided by NPFs, their value, the state of the non-banking financial sector, its benefits, which, as a result, the users are not suffiecient aware of knowledge in making the right decisions regarding the choice of financial service, the assessment of their own risks and their future obligations;

- ineffective regulation and supervision of NPFs. At the legislative level, the National Commission for Regulation of Financial Services Markets is the regulator of the NPFs, but in fact it cannot affect their activity.

Analysis of the main indicators of credit associations' activities

Table 5

\begin{tabular}{|l|c|c|c|c|c|}
\hline \multicolumn{1}{|c|}{ Indicators } & $\mathbf{2 0 1 6}$ & $\mathbf{2 0 1 7}$ & $\mathbf{2 0 1 8}$ & \multicolumn{2}{c|}{ Deviation } \\
\cline { 4 - 6 } & $\mathbf{2 0 1 8 / 2 0 1 6 , \text { abs. }}$ & $\mathbf{2 0 1 8 / 2 0 1 6 , \%}$ \\
\hline $\begin{array}{l}\text { Number of registred credit unions (CU), } \\
\text { thousand of people }\end{array}$ & 462 & 378 & 358 & -104 & -22.5 \\
\hline $\begin{array}{l}\text { Number of members of the Constitutional Court, } \\
\text { thousand of people }\end{array}$ & 642 & 564 & 479 & -163 & -25.4 \\
\hline $\begin{array}{l}\text { Number of credit unions members having } \\
\text { deposits in deposit accounts thousand of people }\end{array}$ & 41 & 21 & 17 & -24 & -58.5 \\
\hline $\begin{array}{l}\text { Number of credit unions members with existing } \\
\text { credit agreement, thousand of people }\end{array}$ & 148 & 134 & 118 & -30 & -20.3 \\
\hline Total assets, million UAH & 2032.5 & 2169.8 & 2218.4 & 185.9 & 9.1 \\
\hline Capital, million UAH & 1044.4 & 1062.5 & 977.1 & -67.3 & -6.4 \\
\hline $\begin{array}{l}\text { Loans to members of the credit unions (balance } \\
\text { for the end of the period), million UAH }\end{array}$ & 1799.5 & 1902.3 & 2018.0 & 218.5 & 12.1 \\
\hline $\begin{array}{l}\text { Members' contributions to deposit accounts } \\
\text { (end-of-period balance), million UAH }\end{array}$ & 831.8 & 937.0 & 1045.7 & 213.9 & 25.7 \\
\hline
\end{tabular}

Designed by authors according to the source [7] 
Conclusions. The analysis of the development of nonbanking institutions in Ukraine has shown that the financial services market is developing with some problems that can be solved. The decline in the number of insurance companies, non-state pension funds, pawnshops, credit unions nevertheless provide growth of the main indicators of the development. In the future, it is necessary to increase the level of public confidence on financial institutions, including non-banking ones, the activities of which contribute to improving the well-being of citizens. Every year the savings of the population and the accumulation of business entities are increasing, the demand for innovation and investment services is increasing, the needs of the domestic economy for additional investment resources are increasing, the country's integration into the international space is observed, which will further determine the role of the $\mathrm{NPF}$ in the development of the financial services market.

\section{References:}

1. Gladchuk O.M., Kucherivska S.S. (2013). Dyjlnist nebankovskyh finansovyh instytutov u suchasnyh umovah vytchiznjnoi ekonomyki [The activities of non-banking financial institutions in the modern conditions of the domestic economy]. Bulletin of the Khmelnitsky National University. Economics sciences. No. 14(1), p. 152-157. URL: http://nbuv.gov.ua/UJRN/Vchnu_ ekon_2013_4(1)_28 (accessed 09 January 2020).

2. Didenko L.V., Kobzar O.P, Hanalieva I.S. (2018). Doslidzhenyj diyjlnosti nebankovskyh finansovyh ustanov jk uchasnikiv suchasnoho rinku finansovih posluh [Research activities of non-banking financial institutions as participants in the modern financial services market]. Economic Analysis. Ternopil. Vol. 28. No 4. P. 88-94.

3. Dubina M.V. (2010). Stan ta perspektyvi rozvytku sistemi parabankivskih Poserednikiv [Status and development prospects of the system of parabank intermediaries]. URL: http://archive.nbuv.gov.ua/ portal/soc_gum./NvFbi/2010_3/08st.p (accessed 09 January 2020).

4. Ivavitska O.M., Guts M.V. (2013). Dyjlnist nebankovskyh kreditno- finansovyh ustanov v Ukraine [The activities of non-bank financial institutions in Ukraine]. Scientific Bulletin of the Institute of International Relations of the NAU. Series: Economics, Law, Political Science, Tourism. Vol. 1, pp. 28-32.

5. Sidelnik O.P. (2011). Pozitsiuvanj nebankovskyh finansovyh ustanov na rinku finansovih posluh jk factor pidvishchenj ih konkurentospromozhnosti [Positioning of non-banking financial institutions in the financial services market as a factor in increasing their competitive ability]. Bulletin of the University of Banking of the NBU. No. 2(1), pp. 237-241. URL: http://www.nbuv.gov.ua/portal/ Soc Gum/VUbsNbU/2011 2/VUBSNBU11 p237-p241 (accessed 09 January 2020).

6. Polishchuk E. (2012). Klasifikatsij nebankovskyh finansovyh ustanov [Classification of non-banking financial institutions]. Securities Market of Ukraine. No. 12. URL: http://securities.usmdi.org/?p=22\&n=74\&s=737 (accessed 09 January 2020).

7. Publichnji zvit pro dijlnist Natsionalnoi komisyi, shcho zdyisnue derzhavne rehuluvanyi u sferi rinkiv finansovih posluh za 2018 rik [Public report on the activities of the National Commission, which carries out state regulation in the field of financial services markets for 2018]. URL: https://www.nfp.gov.ua/ (accessed 10 January 2020).

8. Pro vnesenyi zmin do dejukih zakonodavchih aktiv shchodo udoskonalenij Funktsyi iz derzhavnoho reguluvanyi rinkiv finansovih posluh: Zakon Ukraine vid 12.09.2019 r. № 79-IX [On amendments to certain legislative acts on improving the functions of state regulation of financial services markets: Law of Ukraine of September 12, 2019 No. 79-IX]. URL: https://zakon.rada.gov.ua/laws/ show/79-IX (accessed 10 January 2020).

9. Pidsumki dijlnosti strahovih kompanyi za 9 misytsiv 2019 r. [Results of the activities of insurance companies for 9 months of 2019]. URL: https://www.nfp.gov.ua/files/OgliadRinkiv/SK/sk_9_mis_2019 (accessed 10 January 2020).

10. Zakonoproekt pro Lombardi [Pawnshop bill]. URL: https://news.finance.ua/ua/news/-/462845/v-ukrayini-planuyut-po-novomuvregulyuvaty-diyalnist-lombardiv=28-12-2019 (accessed 11 January 2020).

\section{Список використаних джерел:}

1. Гладчук О.М., Кучерівська С. С. Діяльність небанківських фінансових інститутів у сучасних умовах вітчизняної економіки. Вісник Хмельницького національного університету. Економічні науки. 2013. № 4(1). C. 152-157. URL: http://nbuv.gov.ua/ UJRN/Vchnu_ekon_2013_4(1)_28 (дата звернення: 09.01.2020).

2. Діденко Л.В., Кобзар І.А., Ханалієва І.С. Дослідження діяльності небанківських фінансових установ як учасників сучасного ринку фінансових послуг. Економічний аналіз. Тернопіль, 2018. Том 28. № 4. С. 88-94.

3. Дубина M.В. Стан та перспективи розвитку системи парабанківських посередників: URL: http://archive.nbuv.gov.ua/ portal/soc_gum./NvFbi/2010_3/08st.p (дата звернення: 09.01.2020).

4. Іваницька О.М., Гуц М.В. Діяльність небанківських кредитно-фінансових установ в Україні. Науковий вісник Інституту міжнародних відносин НАУ. Серія : Економіка, право, політологія, туризм. 2013. Вип. 1. С . $28-32$.

5. Сідельник О.П. Позиціонування небанківських фінансових установ на ринку фінансових послуг як фактор підвищення їх конкурентоспроможності. Вісник університету банківської справи Національного банку України. 2011. № 2(1). С. $237-241$. URL: http://www.nbuv.gov.ua/portal/Soc_Gum/VUbsNbU/2011_2/VUBSNBU11_p237-p241 (дата звернення: 09.01.2020).

6. Поліщук Є. Класифікація небанківських фінансових установ. Ринок цінних паперів України. 2012. № 12. URL: http://securities.usmdi.org/?p=22\&n=74\&s=737 (дата звернення: 09.01.2020).

7. Публічний звіт про діяльність Національної комісії, що здійснює державне регулювання у сфері ринків фінансових послуг за 2018 рік. URL: https://www.nfp.gov.ua/ (дата звернення: 10.01.2020).

8. Про внесення змін до деяких законодавчих актів щодо удосконалення функцій із державного регулювання ринків фінансових послуг : Закон України від 12.09.2019 р. №79-IX. URL: https://zakon.rada.gov.ua/laws/show/79-IX (дата звернення: 10.01.2020).

9. Підсумки діяльності страхових компаній за 9 місяців 2019 p. URL: https:/www.nfp.gov.ua/files/OgliadRinkiv/SK/sk_9 mis_2019 (дата звернення: 10.01.2020).

10. Законопроект про ломбарди. URL: https://news.finance.ua/ua/news/-/462845/v-ukrayini-planuyut-po-novomu-vregulyuvatydiyalnist-lombardiv=28-12-2019 (дата звернення: 11.01.2020). 


\section{ТЕОРЕТИЧНІ ТА ПРАКТИЧНІ АСПЕКТИ ДІЯЛЬНОСТІ НЕБАНКІВСЬКИХ ФІНАНСОВИХ УСТАНОВ ТА ЇХ РОЛЬ У РОЗВИТКУ СУЧАСНОГО РИНКУ ФІНАНСОВИХ ПОСЛУГ УКРАЇНИ}

Анотація. У роботі пропонується науковий підхід до визначення місця і ролі небанківських фінансових установ у сучасному розвитку ринку фінансових послуг. Фінансове посередництво здійснює позитивний вплив на розвиток виробництва та інших сфер економіки за допомогою грошових заощаджень суб'єктів господарювання, які є найбільшим джерелом інвестицій в економіку і які перерозподілити без посередників не можливо. Небанківські фінансові установи розглядаються як основні посередники фінансового ринку, діяльність яких пов'язана із створенням спеціальних систем страхування та захисту від фінансових ризиків, із збільшенням дохідності позичкових капіталів, із скороченням витрат основних суб'єктів ринку, пов'язаних із формуванням вільних коштів чи створенням нових фінансових інструментів. Автори аналізують діяльність спеціалізованих фінансових посередників, що займаються на ринку одним видом діяльності: страхових компаній, кредитних спілок, недержавних пенсійних фондів і ломбардів, які $є$ найпоширенішими на вітчизняному ринку фінансових послуг. У статті здійснено аналіз кількісних та якісних показників, які визначають роль фінансових посередників на ринку фінансових послуг України. Висвітлено проблеми, які перешкоджають розвитку небанківських фінансових установ та запропоновано шляхи їх вирішення. У статті здійснено аналіз кількісних та якісних показників, які визначають роль фінансових посередників на ринку фінансових послуг України. Висвітлено проблеми, які перешкоджають розвитку небанківських фінансових установ та запропоновано шляхи їх вирішення. Значна частина посередницьких структур, які досліджуються у роботі, виникла і набула свого розвитку лише у кінці $\mathrm{XX}$ столітті і цей процес не закінчився. Динамічний розвиток економіки, фінансової сфери, менеджменту зумовить появу нових фінансових посередників у світовому масштабі і конкретно в Україні. Дослідження фінансового посередництва, як самостійного економічного явища, має важливе теоретичне і практичне значення, особливо в сучасних умовах, коли формується інфраструктура ринку фінансових послуг і механізм його регулювання.

Ключові слова: ринок фінансових послуг, небанківські фінансові установи, страхові компанії, недержавні пенсійні фонди, кредитні спілки, ломбарди.

\section{ТЕОРЕТИЧЕСКИЕ И ПРАКТИЧЕСКИЕ АСПЕКТЫ ДЕЯТЕЛЬНОСТИ НЕБАНКОВСКИХ ФИНАНСОВЫХ ИНСТИТУТОВ И ИХ РОЛЬ В РАЗВИТИИ СОВРЕМЕННОГО РЫНКА ФИНАНСОВЫХ УСЛУГ}

Аннотация. В работе предлагается научный подход к определению места и роли небанковских финансовых институтов в развитии рынка финансовых услуг. Небанковские финансовые институты рассматриваются как основные посредники финансового рынка, деятельность которых направлена на создание специальных систем страхования и защиты от финансовых рисков, на увеличение доходности кредитного капитала, на сокращение издержек, связанных из созданием новых финансовых продуктов для субъектов рынка. Авторы анализируют деятельность специализованных финансовых посредников, которые занимаются на рынке одним видом деятельности: страхових компаний, кредитних союзов, негосударственных пенсионных фондов и ломбардов, которые являються самыми распространенными інститутами на отечественном рынке финансовых услуг. В статье проведен анализ количественных и качественных показателей, которые определяют роль финансовых посредников на рынке финансовых услуг Украины. Освещены проблемы, которые препятствуют развитию небанковских финансовых институтов и предложены пути их решения.

Ключевые слова: рынок финансовых услуг, небанковские финансовые учреждения, страховые компании, негосударственные пенсионные фонды, кредитные союзы, ломбарды. 